\title{
Progressive Encephalomyelitis With Rigidity and Myoclonus With Thymoma: A Case Report and Literature Review
}

\author{
Yana Su ${ }^{+}$, Li Cui ${ }^{+}$, Mingqin Zhu, Yixuan Liang and Ying Zhang* \\ Department of Neurology and Neuroscience Center, The First Hospital of Jilin University, Changchun, China
}

\section{OPEN ACCESS}

Edited by:

Long-Jun Wu,

Mayo Clinic, United States

Reviewed by:

Daishi Tian,

Huazhong University of Science and

Technology, China

Wei Shihui,

Chinese PLA General Hospital, China

${ }^{*}$ Correspondence:

Ying Zhang

zhang_ying99@jlu.edu.cn

${ }^{\dagger}$ These authors have contributed equally to this work and share first

authorship

Specialty section:

This article was submitted to

Multiple Sclerosis and

Neuroimmunology,

a section of the journal

Frontiers in Neurology

Received: 24 June 2020

Accepted: 03 August 2020

Published: 18 September 2020

Citation:

Su Y, Cui L, Zhu M, Liang Y and

Zhang Y (2020) Progressive Encephalomyelitis With Rigidity and Myoclonus With Thymoma: A Case

Report and Literature Review.

Front. Neurol. 11:1017.

doi: 10.3389/fneur.2020.01017
Progressive encephalomyelitis with rigidity and myoclonus (PERM) is part of the variant type of the Stiff Person Syndrome (SPS) and is a rare neurological disease. We report here a patient with PERM who had thymoma and was positive for anti-glutamic acid decarboxylase (anti-GAD) antibodies. Her symptoms improved after treatment with hormones and gamma globulin. We also summarized the literature review of patients with PERM accompanied by tumors reported.

Keywords: progressive encephalomyelitis with rigidity and myoclonus, thymoma, anti-glycine receptor antibody, anti-glutamic acid decarboxylase antibodies, tumors

\section{INTRODUCTION}

Stiff person syndrome is a rare neurological disease, mainly manifested by axial and limb muscle stiffness, and muscle painful spasms especially after tactile noise, and emotional stress stimulation. Moersch and Wohman (1) first reported in 1956 under the name "Still-man Syndrome." Progressive encephalomyelitis with rigidity and myoclonus is a variant of stiff person syndrome. Its main clinical symptoms are in addition to the typical SPS symptoms, as well as sensory, brainstem symptoms (ataxia, vertigo), spinal cord symptoms, and autonomic symptoms, most patients have anti-glutamic acid decarboxylase (anti-GAD) antibodies, some patients found anti-glycine (GlyR) antibodies. In addition, PERM can be accompanied by tumors, such as thymoma (2-5), Hodgkin's lymphoma (6-8), small cell lung cancer $(9,10)$, breast cancer (11), etc. Here we report a case of GAD antibody- positive PERM associated with thymoma.

\section{CASE PRESENTATION}

A 60-year-old female patient was admitted to the hospital on May 21, 2019 due to "unstable walking and stiff legs for more than 10 days." The patient had instability during walking more than 10 days before admission. Stiff bilateral lower limbs appeared at the time of walking, showing muscle tension in the lower limbs, affecting walking, and falling in severe cases, which gradually eased after about $1 \mathrm{~min}$, and fell 5 times during the course of the disease. Accompanied by itching of the right lower extremity, mainly hip. The above symptoms aggravate after tension, emotional excitement, and touch. The patient denied trauma, infection, poisoning, drugs, psychiatric disease, and family genetic history.

On admission, she was alert and well-oriented. Admission examination of the nervous system: small horizontal nystagmus in both eyes; increased muscle tension in both lower extremities; marked rigidity of her lower limbs were also noticedactive tendon reflexes; hyperreflexia was observed in the extremities, and ankle cramps in both legs. There were no sensory disturbances. 
Laboratory tests: blood routine, urine routine, liver and kidney function, blood lipids, ions, surgical comprehensive, and tumor markers were normal. Thyroid function: T3, T4 normal, TSH: $6.67 \mathrm{uIU} / \mathrm{ml}$, antithyroid peroxidase antibody: $96.51 \mathrm{uIU} / \mathrm{mL}(<35)$, antithyroglobulin antibody: $272.5 \mathrm{uIU} / \mathrm{mL}$ (<115); IG antibody $18 \mathrm{U} / \mathrm{L}(0-12)$; anti-SSA-60 +, granular type 1: 100, anti-SSA-52/Ro52 +, anti-mitochondrial M2 antibody + , high-sensitivity C-reactive protein 6.03 (0-3.5 $\mathrm{mg} / \mathrm{L})$. Cerebrospinal fluid analysis showed no abnormality. The serum anti-GAD antibody IgG was positive and anti-GAD antibody in cerebrospinal fluid was not detected. Anti-islet cell antibody also was positive. Antibodies to Amhiphysin, Yo, Hu, Ri, CV2, Ma2, PCA-2, NMDA receptors, and VGKC were negative in serum. Myasthenia gravis antibodies also were negative. Unfortunately, We were not able to measure anti-glycine antibody titers in our patient due to limited conditions. Neostigmine test: negative.

Head MRI only showed right lacunar infarction. Spinal cord MRI was normal. Electromyographic examination: continuous motor unit activity (CMUA) was seen (Figure 1A). After the injection of $10 \mathrm{mg}$ of diazepam, the CMUA gradually weakened and disappeared (Figure 1B). CT of the thorax revealed an anterior superior mediastinal mass, suggestive of a thymoma.

After admission, pregabalin ( $75 \mathrm{mg}, 2 /$ day) and baclofen ( $10 \mathrm{mg}, 3 /$ day) were given orally, but the symptoms did not improve. And the patient started difficulty water, dysphagia 10 days after admission. So much that a feeding tube was inserted 15 days after admission, binocular dyskinesia suddenly appeared, and eyes paralyzed to the right. Muscle stiffness and myoclonus in both lower extremities gradually increased, and itching in the right lower extremity was unbearable. To some extent, the patient also presented emotional irritability and anxiety. On examination, she was anxious with no evidence of cognitive deterioration. According to the medical history and auxiliary examination results, she was diagnosed with PERM supported by the clinical diagnosis criteria for SPS proposed by Dalakas et al. (12).

After taking the diagnosis of PERM into consideration, the patient was treated with intravenous methylprednisolone therapy (80 $\mathrm{mg} /$ day for 15 days) followed by maintenance therapy with oral methylprednisolone $(60 \mathrm{mg} /$ day $)$. She also received intravenous immune globulin (20g/day) for 3 days. Clonazepam taken orally before bedtime. The patient's eye muscle paralysis disappeared after a few days, there was obvious relief of stiffness of lower limbs, paroxysmal myoclonus, difficulty swallowing, and itching and pain symptoms. Discharged neurological examination (2019-06-26): small horizontal nystagmus in both eyes, gastric tube removal, mild stiffness, and cramps in the lower limbs. Hyperreflexia was still observed in the extremities, and ankle cramps in right leg. The patient's thymoma had surgery indications. In view of the obvious improvement of symptoms and economic reasons, the patient and her family decided to postpone the operation.

After discharge, the methylprednisolone was gradually reduced orally, and clonazepam $1 \mathrm{mg}$ was orally maintained before going to bed. On 2020-1-7 telephone follow-up, the patient experienced another episode of dysphagia and had to keep the gastric tube in the past 20 days. Later, the symptoms gradually improved with the increase of clonazepam dose. Recently, on 2020-7-15 telephone follow-up the patient had difficulty in swallowing again, and her lower limbs were so stiff that she dared not walk independently. As far as the patient's current situation is concerned, we recommend again that the removal of the thymoma and immunotherapy if possible.

\section{DISCUSSION}

In 1976, Whiteley et al. (13) first reported two cases of encephalomyelitis associated with stiff-man syndrome (SPS) and subacute myoclonic spinal neuronitis, which had been classified as stiff-man superposition syndrome, and later confirmed to be progressive encephalomyelitis with rigidity and myoclonus (PERM). With people's understanding of the disease, PERM is found to be a severely life-threatening autoimmune disease characterized by rigidity, muscle pain and spasm, deep and shallow sensory disturbances and symptoms of the brainstem spinal cord, autonomic function, dyspnea, and stimulus-induced myoclonus. The patient here we reported had stiff muscles of the lower extremities, with paroxysmal myoclonus, itching, and pain; the course of the disease gradually develops, difficulty swallowing so severe that need nasal feeding, and paralysis of both eyes to the right; emotional changes and touch stimulation can induce or exacerbate the above symptom. Electromyographic examination: continuous motor unit activity can be seen, found in rectus abdominis, thoracolumbar paravertebral muscle, and proximal

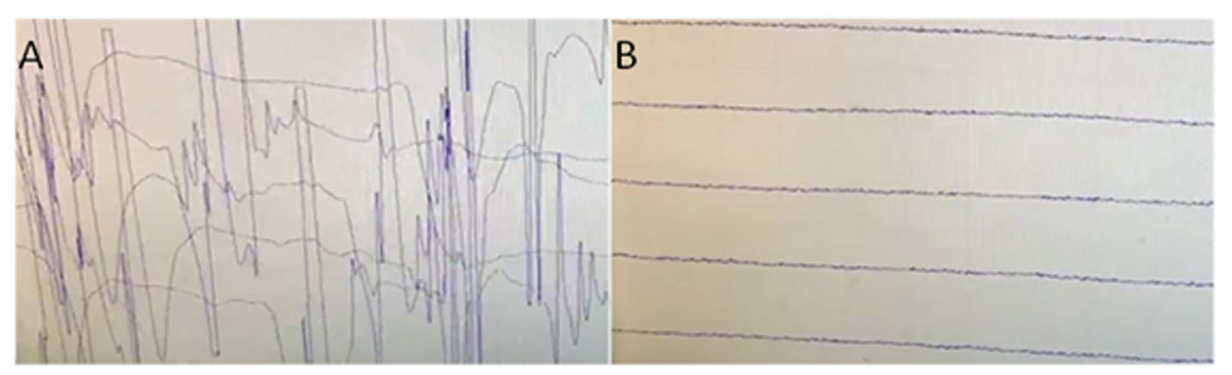

FIGURE 1 | (A) Electromyographic examination: continuous motor unit activity (CMUA)was seen. (B) After the injection of 10 mg of diazepam, the CMUA gradually weakened and disappeared. 
TABLE 1 | Eleven reported cases of PERM associated with tumors; demographics, clinical features, investigation results, management, and outcome.

\begin{tabular}{|c|c|c|c|c|c|c|c|c|c|c|c|c|}
\hline References & $\begin{array}{l}\text { Uehara } \\
\text { et al. (2) }\end{array}$ & Clerinx et al. (3) & $\begin{array}{l}\text { Morise } \\
\text { et al. (4) }\end{array}$ & $\begin{array}{l}\text { Ozaki et al. } \\
\text { (5) }\end{array}$ & $\begin{array}{l}\text { Current } \\
\text { case }\end{array}$ & $\begin{array}{l}\text { Schmidt } \\
\text { et al. (7) }\end{array}$ & $\begin{array}{l}\text { Borellini et al. } \\
\text { (6) }\end{array}$ & $\begin{array}{l}\text { Tchapyjnikov } \\
\text { et al. (8) }\end{array}$ & $\begin{array}{l}\text { Spitz et al. } \\
\text { (9) }\end{array}$ & $\begin{array}{l}\text { Kyskan } \\
\text { et al. (10) }\end{array}$ & $\begin{array}{l}\text { De Blauwe } \\
\text { et al. (11) }\end{array}$ & $\begin{array}{l}\text { Shugaiv et al. } \\
\text { (18) }\end{array}$ \\
\hline \multicolumn{13}{|c|}{ DEMOGRAPHIC } \\
\hline $\begin{array}{l}\text { Age at } \\
\text { onset }\end{array}$ & 52 & 49 & 72 & 75 & 60 & 21 & 60 & 18 & 73 & 39 & 66 & 46 \\
\hline Sex & Female & Male & Female & Female & Female & Male & Male & Male & Male & Male & female & Male \\
\hline \multicolumn{13}{|c|}{ CLINICAL FEATURES } \\
\hline $\begin{array}{l}\text { Initial } \\
\text { symptoms }\end{array}$ & $\begin{array}{l}\text { Awkwardness } \\
\text { in her left leg }\end{array}$ & $\begin{array}{l}\text { Pain in his right } \\
\text { leg }\end{array}$ & $\begin{array}{l}\text { Dysarthria } \\
\text { and chewing } \\
\text { difficulties } \\
\text { with } \\
\text { masticatory } \\
\text { fatigue }\end{array}$ & $\begin{array}{l}\text { Progressive } \\
\text { difficulty in } \\
\text { walking and } \\
\text { rigidity of the } \\
\text { lower } \\
\text { extremities }\end{array}$ & $\begin{array}{l}\text { Stable } \\
\text { walking, stiff } \\
\text { legs }\end{array}$ & $\begin{array}{l}\text { Generalized } \\
\text { pruritus, } \\
\text { paroxysmal } \\
\text { fear, and } \\
\text { disturbance } \\
\text { of sleep }\end{array}$ & $\begin{array}{l}\text { Low back pain } \\
\text { and progressive } \\
\text { rigidity of the } \\
\text { trunk and lower } \\
\text { limbs }\end{array}$ & $\begin{array}{l}\text { Progressive } \\
\text { difficulty } \\
\text { walking and } \\
\text { several falls }\end{array}$ & $\begin{array}{l}\text { Muscular } \\
\text { spasms on } \\
\text { the left lower } \\
\text { limb }\end{array}$ & $\begin{array}{l}\text { A locked left } \\
\text { jaw and leg } \\
\text { myoclonus }\end{array}$ & $\begin{array}{l}\text { Inability to } \\
\text { look to the } \\
\text { left and gait } \\
\text { instability }\end{array}$ & $\begin{array}{l}\text { Diplopia, } \\
\text { dysphagia, } \\
\text { and gait ataxia }\end{array}$ \\
\hline Myoclonus & + & + & + & + & + & + & + & + & + & + & + & + \\
\hline Stiffness & + & + & + & + & + & + & + & + & + & - & - & + \\
\hline Spasm & + & + & + & + & - & + & + & + & + & + & + & + \\
\hline $\begin{array}{l}\text { Brain stem } \\
\text { sign }\end{array}$ & - & $\begin{array}{l}\text { Speech and } \\
\text { swallowing } \\
\text { difficulties } \\
\text { intermittent } \\
\text { diplopia }\end{array}$ & $\begin{array}{l}\text { Abnormalities } \\
\text { in ocular } \\
\text { movements, } \\
\text { dysarthria, } \\
\text { and } \\
\text { dysphagia }\end{array}$ & $\begin{array}{l}\text { Dysarthria, } \\
\text { dysphagia }\end{array}$ & $\begin{array}{l}\text { Difficulty } \\
\text { water, } \\
\text { dysphagia }\end{array}$ & $\begin{array}{l}\text { Bilateral } \\
\text { ptosis and } \\
\text { mydriasis, } \\
\text { hypometric } \\
\text { saccades }\end{array}$ & $\begin{array}{l}\text { Dysphonia } \\
\text { Dysphagia }\end{array}$ & Dysphagia & Dysphagia & $\begin{array}{l}\text { Difficulty } \\
\text { swallowing } \\
\text { food and } \\
\text { could only } \\
\text { open his } \\
\text { mouth } \\
\text { Dysarthria }\end{array}$ & $\begin{array}{l}\text { A bilateral } \\
\text { horizontal } \\
\text { gaze palsy, } \\
\text { hypoesthesia }\end{array}$ & $\begin{array}{l}\text { Diplopia, } \\
\text { dysphagia }\end{array}$ \\
\hline $\begin{array}{l}\text { Nueropsychi } \\
\text { atric } \\
\text { symptom }\end{array}$ & + & - & - & - & - & + & - & + & - & - & - & - \\
\hline Dysautonomia & - & $\begin{array}{l}\text { Dry mouth, } \\
\text { constipation } \\
\text { urinary retention, } \\
\text { and excessive } \\
\text { sweating }\end{array}$ & - & $\begin{array}{l}\text { Urinary } \\
\text { retention, } \\
\text { constipation, } \\
\text { hyperhidrosis, } \\
\text { hypersalivation, } \\
\text { and sinus } \\
\text { tachycardia }\end{array}$ & - & $\begin{array}{l}\text { Tachyarrhythmia, } \\
\text { hyperthermia, } \\
\text { hyperhidrosis, } \\
\text { hypersalivation, } \\
\text { and paralytic } \\
\text { ileus }\end{array}$ & $\begin{array}{l}\text { Hyperhydrosis, } \\
\text { constipation, } \\
\text { and urinary } \\
\text { retention }\end{array}$ & $\begin{array}{l}\text { Urinary } \\
\text { retention }\end{array}$ & - & - & - & - \\
\hline MRI & Normal & Normal & Normal & Normal & Normal & Normal & Normal & Normal & Normal & & Normal & Normal \\
\hline \multicolumn{13}{|l|}{ ANTIBODIES } \\
\hline $\begin{array}{l}\text { GAD } \\
\text { (serum/CSF) }\end{array}$ & $+/+$ & $-1-$ & $+/+$ & $+/+$ & $+/$ na & $-/ \mathrm{na}$ & $-1-$ & $-/$ na & $+/ \mathrm{na}$ & $-/$ na & $-/ \mathrm{na}$ & $-/$ na \\
\hline $\begin{array}{l}\text { GlyR } \\
\text { (serum/CSF) }\end{array}$ & $\mathrm{na} / \mathrm{na}$ & $+/ \mathrm{na}$ & $+1+$ & $+1+$ & $\mathrm{na} / \mathrm{na}$ & + na & $+1+$ & $\mathrm{na} / \mathrm{na}$ & $\mathrm{na} / \mathrm{na}$ & $+/ \mathrm{na}$ & $+/$ na & na/na \\
\hline AchR & - & na & + & - & - & - & na & - & na & - & na & na \\
\hline Amphiphysin & - & - & - & - & - & - & na & - & na & - & - & na \\
\hline Other Abs & - & - & $\begin{array}{l}\text { Anti-thyroid } \\
\text { peroxidase } \\
\text { and anti- } \\
\text { thyroglobulin } \\
\text { antibodies }\end{array}$ & TPO Abs & - & - & - & $\begin{array}{l}\text { Antimicrosomal } \\
\text { and } \\
\text { antithyroglobul- } \\
\text { in } \\
\text { antibodies }\end{array}$ & - & - & - & - \\
\hline Tumor type & Thymoma & Thymoma & Thymoma & Thymoma & Thymoma & $\begin{array}{l}\text { Hodgkin's } \\
\text { lymphoma }\end{array}$ & $\begin{array}{l}\text { Hodgkin's } \\
\text { lymphoma }\end{array}$ & $\begin{array}{l}\text { Hodgkin's } \\
\text { lymphoma }\end{array}$ & Lung cancer & Lung cancer & $\begin{array}{l}\text { Breast } \\
\text { cancer }\end{array}$ & $\begin{array}{l}\text { Renal cell } \\
\text { carcinoma }\end{array}$ \\
\hline
\end{tabular}




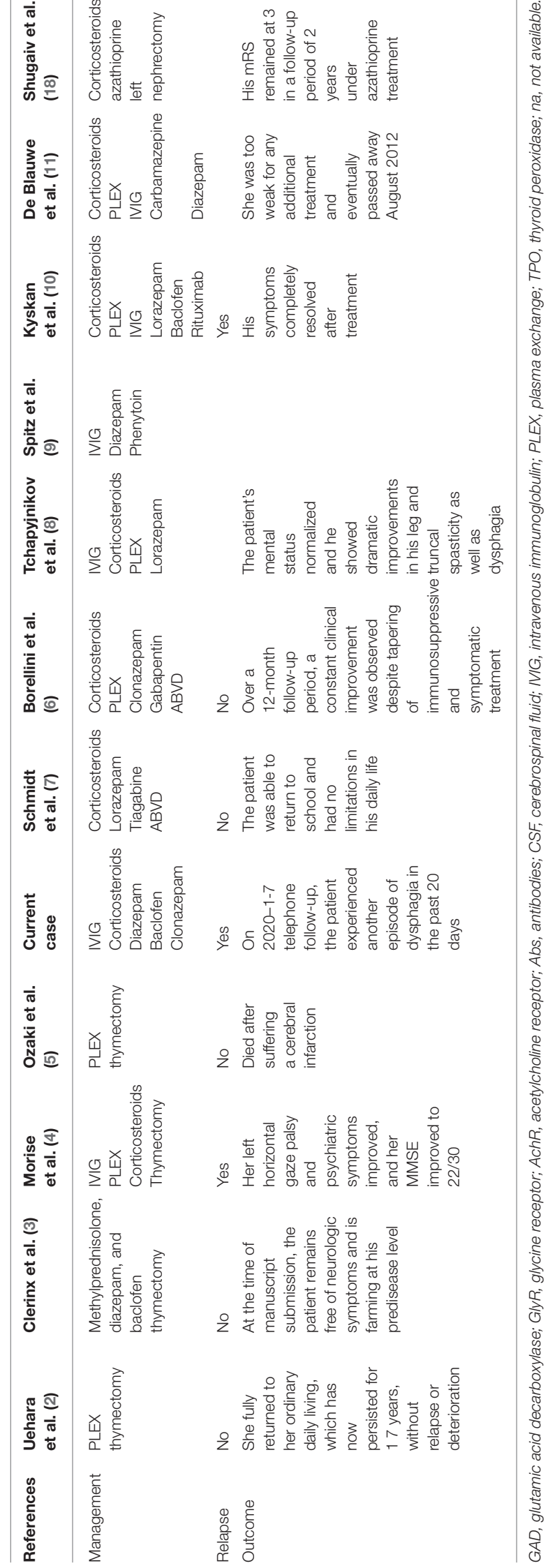

lower limb. After the injection of $10 \mathrm{mg}$ diazepam, the CMUA gradually weakened and disappeared. These clinical symptoms and positive results for anti-GAD antibodies were consistent with PERM. Though there is still no clear diagnostic criteria for PERM. The patient was also accompanied by thymoma. The patient's symptoms improved after treatment with hormones, immunoglobulins, clonazepam, etc. Unfortunately, the patient did not perform thymectomy due to economic reasons and improved symptoms, and the patient experienced relapse of dysphagia, which may be related to the persistent cause of thymoma not removed.

Several neurologic disorders with similar clinical presentations should be considered, including neuromyotonia (NMT), tetanus, and psychogenic dyskinesia. Neuromyotonia is a clinical syndrome characterized by muscle peristalsis, fasciculation, muscle spasm, rigidity, and hyperhidrosis caused by a variety of reasons. Its muscle rigidity is characterized by no relief during sleep, The limbs are more common and rarely involve rectus abdominis. Typical EMG: continuous motor unit activity, slowed movement and sensory conduction, and no response to diazepam, all of which are obviously different from PERM. Tetanus usually has a history of trauma, with masseter muscle spasm as the first symptom. The typical symptom is opisthotonus, and strong muscle spasm caused by external stimuli, ranging from a few seconds to a few minutes each time. It can be distinguished from PERM by the history of trauma, typical symptoms, and the ineffectiveness of tranquilizers, stiff muscles during sleep, and the EMG CMUA can't be completely suppressed by tranquilizers. Psychogenic dyskinesia is mainly manifested as attacks began and ended abrutly, complex and variable manifestations, there are distraction of attention and entrainment effects and co-activation of the affected limb. There are many psychological factors, suggesting or placebo treatment may be effective. Anti-GAD antibodies and EMG are helpful for identification.

The cause of PERM is not clear and may be related to immunity. In recent years, it has been reported that it may be related to anti-glycine receptor (GlyR) antibody. Glycine receptor is a pentameric ligand-gated chloride channel. In the adult nervous system, they are mainly found in the spinal cord and brain stem, which mediate rapid inhibition (14). Antibodies targeted at Glycine receptor may lead to a persistent startle response. Gamma-aminobutyric acid (GABA) is an inhibitory neurotransmitter. Glutamate decarboxylase(GAD) can catalyze the conversion of the excitatory neurotransmitter glutamic acid to GABA. Antibodies against GAD may affect functioning of GABA-ergic neurons (15). All of antibodies target proteins of GABAergic and glycinergic inhibitory synapses, except for dipeptidyl-peptidase-like protein-6 (DPPX)antibodies (16). DPPX antibodies are a regulatory subunit of the Kv4.2 potassium channels on the surface of neurons, which are involved in somatodendritic signal integration and attenuation of back-propagation of action potentials. Patients with DPPX antibodies tend to have hyperekplexia, prominent cerebellar ataxia with marked eye movement disorder, trunk stiffness, sensory disturbance, and gastrointestinal symptoms. Our patient had anti-GAD antibodies which can explain the 


\begin{tabular}{|c|c|c|c|c|c|c|}
\hline Authors & Age/Sex & Clinical features & MRI & Antibodies & Management & Outcomes \\
\hline $\begin{array}{l}\text { Whiteley } \\
\text { et al. (13) }\end{array}$ & $61 / F$ & $\begin{array}{l}\text { Stiffness of her legs and difficulty in walking, shaking of her } \\
\text { legs from time to time, and of precipitancy of micturition }\end{array}$ & & & $\begin{array}{l}\text { Levodopa, diazepam, } \\
\text { orphenadrine, baclofen } \\
\text { dimethothiazine }\end{array}$ & $\begin{array}{l}\text { She died } 13 \text { months after the onset of } \\
\text { her illness }\end{array}$ \\
\hline $\begin{array}{l}\text { Whiteley } \\
\text { et al. (13) }\end{array}$ & 19/M & $\begin{array}{l}\text { Aching pain in his back and legs, weakness of his legs and } \\
\text { difficulty in walking, brief attacks of rigidity and jerking of his } \\
\text { limbs, slurred speech and difficulty swallowing after } 13 \text { days }\end{array}$ & & & & $\begin{array}{l}\text { Twenty-one days after the onset of } \\
\text { his illness, he was found dead on the } \\
\text { floor beside his bed }\end{array}$ \\
\hline $\begin{array}{l}\text { Howell et al. } \\
\text { (19) }\end{array}$ & $56 / F$ & $\begin{array}{l}\text { Vertigo and vomiting, severe burning pain in the left side of } \\
\text { the neck and head, painful spasms, gait instability, difficulty } \\
\text { in chewing, and swallowing }\end{array}$ & & & $\begin{array}{l}\text { Dexamethasone } \\
\text { diazepam }\end{array}$ & $\begin{array}{l}\text { Died after a complex illness lasting } 26 \\
\text { months }\end{array}$ \\
\hline $\begin{array}{l}\text { McCombe } \\
\text { et al. (20) }\end{array}$ & $52 / F$ & $\begin{array}{l}\text { Three months of progressive neurological disturbance. Pain } \\
\text { in the interscapular region, shoulders and chest, numbness } \\
\text { of the hands and arms, weakness of the upper and lower } \\
\text { limbs and urinary retention, episodes of muscle spasms }\end{array}$ & Abnormal & & $\begin{array}{l}\text { Carbamazepine } \\
\text { baclofen, sodium valproate, } \\
\text { and } \\
\text { phenytoin }\end{array}$ & $\begin{array}{l}\text { During a trial of withdrawal of } \\
\text { anticonvulsant therapy, after } 3 \\
\text { months of treatment, the muscle } \\
\text { spasms returned }\end{array}$ \\
\hline $\begin{array}{l}\text { Burn et al. } \\
(21)\end{array}$ & 50/F & $\begin{array}{l}\text { Weakness in her upper limbs, stiffness, and loss of range of } \\
\text { movement in her neck, double vision, mild dysphagia and a } \\
\text { strangled quality to her voice, painful muscle spasm }\end{array}$ & $\begin{array}{l}\text { MRI of the head and } \\
\text { spine was normal }\end{array}$ & $\begin{array}{l}\text { GAD }+ \text { AchR+ gastric } \\
\text { parietal auto-antibody+ } \\
\text { thyroid thyroglobulin } \\
\text { and anti-TMAb + }\end{array}$ & $\begin{array}{l}\text { Diazepam } \\
\text { immunosuppressive therapy } \\
\text { has not been used }\end{array}$ & $\begin{array}{l}\text { Since her initial admission in } \\
\text { September } 1989 \text { the patient's } \\
\text { disabling } \\
\text { spasms and rigidity have slowly } \\
\text { worsened }\end{array}$ \\
\hline $\begin{array}{l}\text { Kullmann } \\
\text { et al. (22) }\end{array}$ & $39 / \mathrm{M}$ & $\begin{array}{l}\text { Dysphagia, dysarthria, nausea, pain in the throat and neck, } \\
\text { and positional vertigo, facial, and nuchal jerks after } \\
2 \text { weeks, myoclonus }\end{array}$ & $\begin{array}{l}\text { MRI of the head with } \\
\text { gadolinium } \\
\text { enhancement } \\
\text { were normal }\end{array}$ & $\begin{array}{l}\text { Positive gastric parietal } \\
\text { and islet cell } \\
\text { antibodies }\end{array}$ & $\begin{array}{l}\text { Carbamazepine } \\
\text { sodium valproate } \\
\text { clonazepam } \\
\text { midazolam }\end{array}$ & $\begin{array}{l}\text { Seven years after presentation, he } \\
\text { continues to have mild generalized } \\
\text { myoclonic jerks }\end{array}$ \\
\hline $\begin{array}{l}\text { Kullmann } \\
\text { et al. (22) }\end{array}$ & $34 / \mathrm{M}$ & $\begin{array}{l}\text { Disturbance of taste, anorexia, and insomnia, } 4 \text { weeks later } \\
\text { he developed dysphagia, painful jerks, muscular rigidity and } \\
\text { myoclonus, tachycardia, hypertension, and mydriasis }\end{array}$ & $\begin{array}{l}\text { Repeated brain and } \\
\text { spinal cord MRI was } \\
\text { again normal }\end{array}$ & & $\begin{array}{l}\text { Corticosteroids } \\
\text { PLEX } \\
\text { Clonazepam } \\
\text { Baclofen } \\
\text { Sodium valproate }\end{array}$ & $\begin{array}{l}\text { Subsequent to discharge, all his } \\
\text { abnormal signs resolved, } \\
\text { stimulus-sensitive jerks recurred on } \\
\text { attempting to discontinue } \\
\text { clonazepam }\end{array}$ \\
\hline $\begin{array}{l}\text { Back et al. } \\
\text { (23) }\end{array}$ & $27 / M$ & $\begin{array}{l}\text { Cerebellar ataxia and dementia, followed by rigidity and } \\
\text { oculomotor dysfunction }\end{array}$ & Abnormal & & $\begin{array}{l}\text { Corticosteroids, Azathioprine, } \\
\text { tizanidin, carbamazepine } \\
\text { baclofen, diazepam }\end{array}$ & $\begin{array}{l}\text { He died } 33 \text { months } \\
\text { after onset of symptoms }\end{array}$ \\
\hline $\begin{array}{l}\text { Kraemer } \\
\text { et al. (17) }\end{array}$ & $81 / F$ & $\begin{array}{l}\text { Severe rigidity, stiffness and superimposed muscle spasms, } \\
\text { tachycardia, hyperhidrosis and arterial hypertension, urine } \\
\text { and stool incontinent, moderate dysphagia }\end{array}$ & $\begin{array}{l}\text { The MRI of the brain } \\
\text { and the whole spine } \\
\text { showed no } \\
\text { abnormalities }\end{array}$ & $\begin{array}{l}\text { GAD+ } \\
\text { TPO+ }\end{array}$ & $\begin{array}{l}\text { IVIG } \\
\text { Corticosteroids } \\
\text { Benzodiazepines } \\
\text { baclofen, vigabatrin }\end{array}$ & $\begin{array}{l}\text { A few months later her gait had } \\
\text { suddenly become more unsteady. } \\
\text { The rigidity of the right leg had } \\
\text { worsened }\end{array}$ \\
\hline $\begin{array}{l}\text { Saidha } \\
\text { et al. (24) }\end{array}$ & 60/F & $\begin{array}{l}\text { Paraspinal muscle rigidity, muscle spasms and new onset } \\
\text { scoliosis, ataxic gait with dysmetria and deteriorating } \\
\text { mobility. Scanning dysarthria, dysmetria, and intention } \\
\text { tremor }\end{array}$ & $\begin{array}{l}\text { MRI of brain and } \\
\text { spine were normal }\end{array}$ & $\begin{array}{l}\text { GAD+,ICA+,TPO+ } \\
\text { AAA+, } \\
\text { anti-transglutaminase, } \\
\text { and anti-endomysial } \\
\text { antibodies + }\end{array}$ & $\begin{array}{l}\text { Corticosteroids } \\
\text { PLEX,IVIG } \\
\text { Methotrexate, azathioprine, } \\
\text { Mycophenolate mofetil, } \\
\text { Infliximab, rituximab } \\
\text { Benzodiazepines }\end{array}$ & $\begin{array}{l}\text { Dysarthria also improved, as did } \\
\text { mobility and she was able to walk } \\
\text { using cross bars }\end{array}$ \\
\hline $\begin{array}{l}\text { Hutchinson } \\
\text { (25) }\end{array}$ & $54 / \mathrm{M}$ & $\begin{array}{l}\text { Left flank tingling and } 2 \text { weeks of worsening brief frequent } \\
\text { violent jerks, spontaneous, and triggered by sensory and } \\
\text { auditory stimuli; Four weeks after admission he developed } \\
\text { mild bilateral ptosis, bilateral partial horizontal gaze palsies }\end{array}$ & $\begin{array}{l}\text { Cranial and spinal } \\
\text { MRI scans with } \\
\text { gadolinium were } \\
\text { normal }\end{array}$ & GlyR+ & $\begin{array}{l}\text { Corticosteroids } \\
\text { PLEX } \\
\text { Cyclophosphamide } \\
\text { Levetiracetam } \\
\text { Clonazepam }\end{array}$ & $\begin{array}{l}\text { Now he is stable with mild spinal } \\
\text { rigidity, } \\
\text { walks } 200 \mathrm{~m} \text { with one stick, and } \\
\text { works part time; horizontal gaze is } \\
\text { normal }\end{array}$ \\
\hline
\end{tabular}




\begin{tabular}{|c|c|c|c|c|c|c|}
\hline Authors & Age/Sex & Clinical features & MRI & Antibodies & Management & Outcomes \\
\hline $\begin{array}{l}\text { Mas et al. } \\
\text { (26) }\end{array}$ & $33 / F$ & $\begin{array}{l}\text { Diplopia, dysphagia, and gait ataxia, progressively } \\
\text { developed rigidity of lower limbs with painful spasms, } \\
\text { involuntary jerks and contracture of both ankles and urinary } \\
\text { retention }\end{array}$ & $\begin{array}{l}\text { Brain and spinal MRI } \\
\text { and was normal }\end{array}$ & GlyR+ & $\begin{array}{l}\text { Corticosteroids } \\
\text { IVIG } \\
\text { Diazepam } \\
\text { and baclofen }\end{array}$ & $\begin{array}{l}\text { She has been asymptomatic for } 8 \\
\text { years }\end{array}$ \\
\hline $\begin{array}{l}\text { Mas et al. } \\
(26)\end{array}$ & $60 / M$ & $\begin{array}{l}\text { Dysphagia, diplopia, left facial palsy and right trigeminal } \\
\text { hypoaesthesia, muscular rigidity, corticospinal signs, } \\
\text { myoclonic jerks, and severe dysautonomia }\end{array}$ & $\begin{array}{l}\text { Brain MRI were } \\
\text { normal }\end{array}$ & GlyR+ & & $\begin{array}{l}\text { He has remained in a persistent } \\
\text { vegetative state and } \\
\text { ventilator-dependent }\end{array}$ \\
\hline $\begin{array}{l}\text { Mas et al. } \\
\text { (26) }\end{array}$ & $48 / \mathrm{M}$ & $\begin{array}{l}\text { Leg rigidity and frequent spells of trismus, muscle spasms } \\
\text { followed by opisthotonus and diaphoresis. Progressively } \\
\text { more aggressive with emotional irritability. Dysgeusia } \\
\text { (metallic taste) and severe concurrent behavioral changes } \\
\text { and diurnal hypersomnia }\end{array}$ & $\begin{array}{l}\text { Brain and spinal MRI } \\
\text { scans were normal }\end{array}$ & GlyR+ & $\begin{array}{l}\text { Corticosteroids } \\
\text { IVIG } \\
\text { Diazepam } \\
\text { gabapentin }\end{array}$ & $\begin{array}{l}\text { His leg stiffness was partially } \\
\text { improved but persistence of the } \\
\text { pruritus, dysgeusia, hypersomnia, } \\
\text { masseter spasms with yawn, and } \\
\text { behavioral changes }\end{array}$ \\
\hline $\begin{array}{l}\text { Turner et al. } \\
\text { (27) }\end{array}$ & $28 / M$ & $\begin{array}{l}\text { Seizures and erectile dysfunction } 3 \text { weeks later urinary } \\
\text { retention, jerky eye movements, ataxia, limb rigidity with } \\
\text { myoclonus }\end{array}$ & $\begin{array}{l}\text { MRI of the brain and } \\
\text { whole spine } \\
\text { were normal. }\end{array}$ & $\begin{array}{l}\text { GlyR+ } \\
\text { NMDAR+ }\end{array}$ & Levetiracetam & $\begin{array}{l}\text { Death within days of admission from } \\
\text { multi-organ failure }\end{array}$ \\
\hline $\begin{array}{l}\text { lizuka et al. } \\
\text { (28) }\end{array}$ & $61 / F$ & $\begin{array}{l}\text { Reduced sense of taste, A week later she began to feel } \\
\text { stiffness, back pain, then myoclonic jerks and painful } \\
\text { spasms dysphagia,dysarthria, left gaze palsy, right-gaze } \\
\text { evoked counterclockwise rotatory nystagmus, and slow } \\
\text { saccade to the left }\end{array}$ & $\begin{array}{l}\text { Brain, cervical, } \\
\text { thoracic, and lumbar } \\
\text { MRls were normal }\end{array}$ & $\begin{array}{l}\text { TPO+ } \\
\text { Tg-Abs }\end{array}$ & $\begin{array}{l}\text { IVMP, IVIg, } \\
\text { Corticosteroids } \\
\text { Cyclosporine } \\
\text { Baclofen, diazepam } \\
\text { Clonazepam }\end{array}$ & $\begin{array}{l}\text { Initially improved but } \\
\text { twice relapsed } \\
\text { ( } 40 \text { months) }\end{array}$ \\
\hline $\begin{array}{l}\text { Peeters } \\
\text { et al. (29) }\end{array}$ & $37 / M$ & $\begin{array}{l}\text { A 1-month-history of muscle jerks, painful spasms, falls, } \\
\text { diplopia, dysphagia, incomplete jaw opening, constipation, } \\
\text { urinary retention, and pruritus of the arms and back }\end{array}$ & $\begin{array}{l}\text { Brain and spinal MRI } \\
\text { were normal }\end{array}$ & GlyR+ & $\begin{array}{l}\text { Corticosteroids } \\
\text { PLEX } \\
\text { Diazepam } \\
\text { baclofen }\end{array}$ & $\begin{array}{l}\text { Upon discharge neurological exam } \\
\text { was normal, apart from mild } \\
\text { hypertonia of the limbs and slightly } \\
\text { slowed upward saccades }\end{array}$ \\
\hline $\begin{array}{l}\text { Shugaiv } \\
\text { et al. (18) }\end{array}$ & $54 / \mathrm{M}$ & $\begin{array}{l}\text { Difficulty walking and profuse sweating, generalized } \\
\text { stiffness, rigidity and upward gaze restriction, he had right } \\
\text { central facial palsy, spastic paraparesis, myoclonic jerks, } \\
\text { and startle response }\end{array}$ & $\begin{array}{l}\text { Cranial and spinal } \\
\text { MRI scans were } \\
\text { normal }\end{array}$ & None & $\begin{array}{l}\text { Corticosteroids } \\
\text { IVIG }\end{array}$ & $\begin{array}{l}\text { The patient did not respond to } 7 \\
\text { pulse steroid and intravenous IVlg } \\
\text { treatment courses performed on } \\
\text { several occasions }\end{array}$ \\
\hline $\begin{array}{l}\text { Shugaiv } \\
\text { et al. (18) }\end{array}$ & $67 / M$ & $\begin{array}{l}\text { Amnesia, left focal motor seizures. Within } 2 \text { months, } \\
\text { generalized rigidity, stiffness, myoclonic jerks, dysphagia, } \\
\text { and mutism followed by stupor }\end{array}$ & $\begin{array}{l}\text { Cranial and spinal } \\
\text { MRI scans were } \\
\text { normal }\end{array}$ & $\begin{array}{l}\text { GAD+ } \\
\text { LGI1+ } \\
\text { VGKC+ }\end{array}$ & $\begin{array}{l}\text { Corticosteroids } \\
\text { IVIG } \\
\text { Anticonvulsants }\end{array}$ & $\begin{array}{l}\text { He has not developed new symptoms } \\
\text { in a follow-up period of } 3 \text { years }\end{array}$ \\
\hline $\begin{array}{l}\text { Joana et al. } \\
\text { (30) }\end{array}$ & 14months./M & $\begin{array}{l}\text { Irritability, restless sleep, and sudden episodes of axial } \\
\text { hyperextension, rigidity, and generalized myoclonus. Soon } \\
\text { after, she developed laterocollis to the right, left hemifacial } \\
\text { spasm, trismus, and urinary retention }\end{array}$ & & GlyR+ & $\begin{array}{l}\text { Corticosteroids } \\
\text { IVIG } \\
\text { Levetiracetam } \\
\text { Clonazepam }\end{array}$ & $\begin{array}{l}\text { The paroxysms disappeared } 10 \text { days } \\
\text { after starting } \\
\text { immunotherapy }\end{array}$ \\
\hline $\begin{array}{l}\text { Stern et al. } \\
(31)\end{array}$ & $40 / M$ & $\begin{array}{l}\text { Prodrome of mood disturbance and } \\
\text { myoclonic jerks. One week later presented with rigidity, } \\
\text { ophthalmoplegia, myoclonus, sweating }\end{array}$ & $\begin{array}{l}\text { Magnetic resonance } \\
\text { (MR) brain imaging } \\
\text { were normal }\end{array}$ & GlyR+ & $\begin{array}{l}\text { IVIG PLEX } \\
\text { Corticosteroids clonazepam } \\
\text { Baclofen }\end{array}$ & $\begin{array}{l}\text { Gradual response but } \\
\text { relapsed at } 7 \text { months }\end{array}$ \\
\hline $\begin{array}{l}\text { Wuerfel } \\
\text { et al. (32) }\end{array}$ & $3 / \mathrm{M}$ & $\begin{array}{l}\text { Generalized epilepsy, Seizures, tamper tantrums, } \\
\text { headaches, and sleep disturbance }\end{array}$ & $\begin{array}{l}\text { Cranial MRI at } 3.0 \\
\text { Tesla } \\
\text { was normal. }\end{array}$ & GlyR+ & Corticosteroids lamotrigine & \\
\hline $\begin{array}{l}\text { Balint } \\
\text { et al.(33) }\end{array}$ & $16 / M$ & $\begin{array}{l}\text { Unsteadiness of the right arm and excessive startle, } \\
\text { scoliosis, thoracic spine, trunk stiffness }\end{array}$ & $\begin{array}{l}\text { MRI of the brain was } \\
\text { normal }\end{array}$ & DPPX+ & $\begin{array}{l}\text { IVIG, } \\
\text { PLEX } \\
\text { Corticosteroids } \\
\text { Rituximab } \\
\text { Benzodiazepines }\end{array}$ & $\begin{array}{l}\text { At follow-up } 21 \text { months after } \\
\text { symptom onset, normal walking was } \\
\text { unimpeded, but tandem gait and } \\
\text { standing on one leg were impossible }\end{array}$ \\
\hline
\end{tabular}

developed rigidity of lower limbs with painful spasms,

retention

hypoaesthesia, muscular rigidity, corticospinal signs,

Leg rigidity and frequent spells of trismus, muscle spasm

opisthotonus and diaphoresis. Progressively

more aggressive with emotional irritability. Dysgeusia

(metallic taste) and severe concurrent behavioral changes

Seizures and erectile dysfunction 3 weeks later urinary

retention, jerky eye movements, ataxia, limb rigidity with myoclonus

spasms dysphagia, dysarthria, left gaze palsy, right-gaze

saccade to the let

$a$

diplopia, dysphagia incomplete jaw opening, constipation,

Difficulty walking and profuse sweating, generalized

stiffness, rigidity and upward gaze restriction, he had right

central facial palsy, spastic paraparesis, myoclonic jerks, and mutism followed by stupor

the right, left hemifacia

, trismus, and urinary retention 


\begin{tabular}{|c|c|c|c|c|c|c|}
\hline Authors & Age/Sex & Clinical features & MRI & Antibodies & Management & Outcomes \\
\hline $\begin{array}{l}\text { Balint et al. } \\
\text { (33) }\end{array}$ & $27 / M$ & $\begin{array}{l}\text { Muscular stiffness, jerky spasms after } 4 \text { years constipation } \\
\text { developed, blurred vision on external gaze and acrophobia. } \\
\text { recently, paraesthesia and allodynia }\end{array}$ & $\begin{array}{l}\text { MRI of brain and } \\
\text { spine were normal }\end{array}$ & $\mathrm{DPXX}+$ & $\begin{array}{l}\text { IVIG } \\
\text { Corticosteroids } \\
\text { Rituximab } \\
\text { Clonazepam }\end{array}$ & $\begin{array}{l}\text { The clinical course was stable for } 2 \\
\text { years with the abovementioned } \\
\text { treatment regimen }\end{array}$ \\
\hline $\begin{array}{l}\text { Balint et al. } \\
\text { (33) }\end{array}$ & $26 / M$ & $\begin{array}{l}\text { Unclassified ocular motor disturbance and hyperhidrosis. } \\
\text { By then, broken pursuit and gaze-evoked nystagmus, trunk } \\
\text { stiffness, Jerks, slurred, and scanning speech as well as } \\
\text { gait and limb ataxia. Intense allodynia and neurogenic } \\
\text { pruritus, memory and attention deficits, hyperreflexia, } \\
\text { urinary retention }\end{array}$ & $\begin{array}{l}\text { MRI of the brain and } \\
\text { the spine were } \\
\text { initially normal. } \\
\text { Seventeen years } \\
\text { after onset, MRI of } \\
\text { the brain disclosed } \\
\text { mild cerebellar } \\
\text { atrophy }\end{array}$ & DPPX+ & $\begin{array}{l}\text { IVIG, } \\
\text { PLEX } \\
\text { Corticosteroids } \\
\text { Cyclophosphamide }\end{array}$ & $\begin{array}{l}\text { Due to dysphagia, he recurrently } \\
\text { contracted severe pneumonia } \\
\text { requiring intensive care treatment, } \\
\text { which eventually led to death }\end{array}$ \\
\hline $\begin{array}{l}\text { Bourke } \\
\text { et al.(34) }\end{array}$ & $55 / \mathrm{M}$ & $\begin{array}{l}24 \text { months of progressive stiffness and pain in his legs, jerks } \\
\text { of his entire body and painful extensor spasms of his limbs } \\
\text { and trunk. then hyperekplexia }\end{array}$ & $\begin{array}{l}\text { MRI of the brain was } \\
\text { normal. }\end{array}$ & GlyR+ & $\begin{array}{l}\text { IVIG,Azathioprine } \\
\text { Corticosteroids } \\
\text { Clonazepam, diazepam } \\
\text { phenytoin, baclofen }\end{array}$ & $\begin{array}{l}\text { Five years after presentation he was } \\
\text { living independently with moderate } \\
\text { rigidity, a slow and stiff gait }\end{array}$ \\
\hline $\begin{array}{l}\text { Bourke } \\
\text { et al. (34) }\end{array}$ & $58 / F$ & stiffness in the legs, body jolts, loss of consciousness & $\begin{array}{l}\text { Cranial and spinal } \\
\text { MRI with were } \\
\text { normal }\end{array}$ & GlyR+ & $\begin{array}{l}\text { Corticosteroids } \\
\text { Methotrexate } \\
\text { Diazepam } \\
\text { Clonazepam }\end{array}$ & She has remained in remission \\
\hline $\begin{array}{l}\text { Seguier } \\
\text { et al. (35) }\end{array}$ & $73 / F$ & $\begin{array}{l}\text { Abdominal pain,then hypophonia and dyspnea, cognitive } \\
\text { impairment and stuttering, muscle cramps }\end{array}$ & normal & & $\begin{array}{l}\text { IVIG Diazepam } \\
\text { Corticosteroids } \\
\text { Benzodiazepines } \\
\text { Rituximab }\end{array}$ & \\
\hline $\begin{array}{l}\text { Ueno et al. } \\
\text { (36) }\end{array}$ & $48 / F$ & $\begin{array}{l}\text { Spasticity of the lower limbs and subsequently developed } \\
\text { upper limb spasticity, perioral myoclonus and restlessness } \\
\text { after } 3 \text { months, dysautonomia }\end{array}$ & $\begin{array}{l}\text { MRI of the } \\
\text { brain/pelvis were } \\
\text { normal }\end{array}$ & None & $\begin{array}{l}\text { IVIG } \\
\text { Levetiracetam azathioprine } \\
\text { Diazepam }\end{array}$ & $\begin{array}{l}\text { Patient showed a } \\
\text { dramatic improvement following } \\
\text { immune moderation }\end{array}$ \\
\hline $\begin{array}{l}\text { Kenda et al. } \\
\text { (37) }\end{array}$ & $67 / M$ & $\begin{array}{l}\text { Four weeks history of speech and swallowing difficulties, } \\
\text { leg weakness, and shortness of breath. Twitching of his } \\
\text { face and limb muscles }\end{array}$ & $\begin{array}{l}\text { Brain MRI was } \\
\text { unremarkable }\end{array}$ & GlyR+ & $\begin{array}{l}\text { Immunoadsorption } \\
\text { PLEX } \\
\text { Levetiracetam azathioprine } \\
\text { Diazepam }\end{array}$ & $\begin{array}{l}\text { One year from symptom onset, he } \\
\text { suffered from disease relapse }\end{array}$ \\
\hline $\begin{array}{l}\text { Degeneffe } \\
\text { et al. (38) }\end{array}$ & $62 / F$ & $\begin{array}{l}\text { Lower back pain, lumbar muscular contractures, and back } \\
\text { rigidity. Then lower limb, myoclonus, confusion, } \\
\text { hyperthermia, and acute respiratory failure }\end{array}$ & $\begin{array}{l}\text { Brain and spinal } \\
\text { magnetic resonance } \\
\text { imaging (MRI) } \\
\text { revealed a pituitary } \\
\text { adenoma }\end{array}$ & GAD+ & $\begin{array}{l}\text { IVIG } \\
\text { PLEX } \\
\text { Corticosteroids } \\
\text { Levetiracetam }\end{array}$ & $\begin{array}{l}\text { Seven months after admission, she } \\
\text { had no relapse of the myoclonus nor } \\
\text { the rigidity and was able to walk } \\
\text { without assistance }\end{array}$ \\
\hline $\begin{array}{l}\text { Wirth et al. } \\
\text { (39) }\end{array}$ & $61 / \mathrm{M}$ & $\begin{array}{l}\text { within a few days, right eyelid ptosis and diplopia. Two } \\
\text { weeks later, he experienced widespread painful spasms, } \\
\text { multifocal stimulus-sensitive myoclonus followed by } \\
\text { hypertonic tetraparesis, swallowing difficulties, somnolence, } \\
\text { and respiratory failure }\end{array}$ & Abnormal & $\begin{array}{l}\text { GlyR+ } \\
\text { VGKC+ } \\
\text { LGl1+ } \\
\text { CASPR2+ }\end{array}$ & $\begin{array}{l}\text { IVIG } \\
\text { Corticosteroids } \\
\text { Botulinum toxin } \\
\text { Cyclophosphamide } \\
\text { Diazepam } \\
\text { Baclofen }\end{array}$ & $\begin{array}{l}\text { When reevaluated } 3 \text { months later, the } \\
\text { patient remained stiff in all four limbs, } \\
\text { but was nonetheless able to walk }\end{array}$ \\
\hline $\begin{array}{l}\text { Witek et al. } \\
(40)\end{array}$ & $55 / F$ & $\begin{array}{l}\text { Intellectual disability, immobility, and inability to swallow } \\
\text { safely after } 1 \text { week, mild bifacial weakness, profound axial } \\
\text { and limb rigidity, severe dysarthria, and polyminimyoclonus } \\
\text { in her jaw and distal aspects of her extremities }\end{array}$ & Normal & GAD65+ & $\begin{array}{l}\text { IVIG } \\
\text { Corticosteroids } \\
\text { Benzodiazepines } \\
\text { Rituximab }\end{array}$ & $\begin{array}{l}\text { Months after her initial presentation, } \\
\text { she has not had any signs of a relapse } \\
\text { of her symptoms }\end{array}$ \\
\hline
\end{tabular}


excessive neuronal activities resulting in the typical clinical symptoms. However, Our case simultaneously had many other antibodies but not meet the disease diagnosis criteria, such as antithyroid peroxidase antibody, anti-islet cell antibody, antithyroglobulin antibody, anticardiolipin IgG antibody, antiSSA-60, granular type, anti-SSA-52/Ro52, anti-mitochondrial M2 antibody in her serum, which indicated the involvement of immune dysfunction. SPS and PERM are associated with other autoimmune conditions including diabetes mellitus, thyroiditis, autoimmune thyroid disorders, and pernicious anemia. Kraemer et al. reported a case of PERM that hypothyroidism was diagnosed 3 months before first motor symptoms and that both, the Hashimoto's thyroiditis and the diabetes mellitus were of recent onset (17). Therefore, it is still necessary for our patient to surveillance the development of potentially autoimmune diseases, such as thyroiditis and diabetes. The mechanisms of interaction between these antibodies need further investigation.

We summarized the cases of PERM reported in recent years (Tables 1, 2) and found that there are more men than women, and the reason for this difference is unknown. The age of onset varies, the age range at presentation is 14 months -81 years with a mean of 50 years. Patients with tumors are generally older. Patients have a variety of onset symptoms. Approximately $35 \%$ of patients have onset of muscle stiffness and spasms, and 25\% of patients have onset of brainstem symptoms. However, the clinical manifestations are mainly stiff spasms of the trunk and limb muscles, accompanied by brainstem spinal cord symptoms, including eye movement paralysis, gaze paralysis, nystagmus and drooping eyelids, difficulty swallowing, and difficulty articulating. In general, patients will have obvious autonomic symptoms such as sweating, tachycardia, and urinary retention and even autonomic failure, which may include respiratory failure, and must be managed in intensive care. Twenty-five percentage of the patients require mechanical ventilation and mortality up to $40 \%$ (42). In most patients, there is no abnormality of the head and spinal cord magnetic resonance. MRI of one patient showed increased signal intensity throughout the length of the cervical cord and lower brainstem on the T2 weighted scan and reduced signal intensity in this region on the $\mathrm{Tl}$ weighted scan (20). MRI with diffusion-weighted and fluid-attenuated inversion recovery (FLAIR) weighted sequences (WS) of one patient showed left temporal and insular cortical hyperintensities without gadolinium enhancement (39). MRI of the head in 2 patients showed cerebellar atrophy $(23,33)$. MRI can differentially diagnose other diseases. EMG has diagnostic significance, and the emergence of CMUA is one of the important diagnostic criteria.

The incidence rate of tumor in our statistics are about $20 \%$, which is consistent with the previous literature report (43). We summarized these 12 cases in Table 1. There were 5 cases with thymoma (2-5), 3 cases with Hodgkin's lymphoma (6-8), 2 cases with lung cancer $(9,10), 1$ case with breast cancer (11), 1 case with kidney cancer (18). All 7 patients who tested for GlyR antibodies were positive for GlyR antibodies. Almost all patients tested for GAD antibodies, but less than half of the patients were positive for GAD antibodies. Among the 12 patients with 
tumors, patients with glycine antibody positive were more likely to have dysautonomia.

A retrospective analysis recently found GlyR antibodies in patients of PERM, some of these also had GAD antibodies, DPPX antibodies (33), NMDAR antibodies (27). Patients with GlyR antibodies often have prominent brainstem involvement, and often sensory and autonomic symptoms. GAD antibodies associate with palatal myoclonus, epilepsy, sporadic progressive ataxia. Patients with DPPX antibodies tend to have hyperekplexia, prominent cerebellar ataxia with marked eye movement disorder, trunk stiffness, sensory disturbance, and gastrointestinal symptoms. Multiple antibodies found in some patients of PERM. Therefore, it is difficult to predict the specificity of these antibodies in PERM based on clinical evidence. Further research is needed to clarify each of their roles in PERM. When we consider that a patient may be diagnosed with PERM, we should screen for related antibodies as much as possible.

The treatment of PERM mainly includes symptomatic treatment and immunotherapy. There were 5 patients with thymoma among the patients with tumor, 4 of whom responded well to thymectomy. There were 3 patients with Hodgkin's lymphoma among the patients with tumor, 2 of whom responded well to ABVD chemotherapy. Patients with lung cancer, breast cancer, and kidney cancer have a poor prognosis. The stabilization and recovery may occur if the underlying tumor is detected and treated early. Therefore, in the early stage of diagnosis, tumors should be screened comprehensively, irrespective of the serology in all patients. Most cases of PERM without tumors showed substantial and sustained improvement with immunotherapies, usually with combinations of corticosteroids, IVIg, and plasma exchange, and Rituximab has been reported to have a significant effect.

We reported a patient with PERM who had thymoma and was positive for anti-GAD antibodies, and also summarized the current literature on clinical characteristics, investigation results, management, and outcome of patients of PERM. At the same time, this case also has some limitations, such that we can't measure the anti-glycine antibody titers due to limited lab conditions. In addition, the patient did not perform thymectomy

\section{REFERENCES}

1. Moersch FP, Woltman HW. Progressive fluctuating muscular rigidity and spasm ("stiff-man" syndrome); report of a case and some observations in 13 other cases. Proc Staff Meet Mayo Clin. (1956) 31:421-7.

2. Uehara T, Murai H, Yamasaki R, Kikuchi H, Shigeto H, Ohyagi Y, et al. Thymoma-associated progressive encephalomyelitis with rigidity and myoclonus successfully treated with thymectomy and intravenous immunoglobulin. Eur Neurol. (2011) 66:328-30. doi: 10.1159/000332033

3. Clerinx K, Breban T, Schrooten M, Leite MI, Vincent A, Verschakelen J, et al. Progressive encephalomyelitis with rigidity and myoclonus: resolution after thymectomy. Neurology. (2011) 76:303-4. doi: 10.1212/WNL.0b013e318207b008 due to economic reasons that maybe result in the patient experienced relapse of dysphagia after being discharged. When encountering similar clinical manifestations, it will be better to test related antibodies as comprehensively as possible and actively advise patients to perform surgical treatment to remove the original lesion to prevent recurrence. We hope that this report will provide a basis for further understanding of PERM and mention clinical doctors better identify and treat these similar presentations so as not to delay diagnosis and treatment.

PERM is a complex autoimmune disease that requires a clinician to diagnose it in combination with the patient's symptoms and signs and auxiliary examinations. With the indepth study of PERM and the further development of detection technologies such as GAD antibodies and anti-glycine antibodies, people have gradually deepened their understanding of PERM disease, but the diagnosis still lacks specific antibodies. Further investigation is needed to uncover the nature of disease.

\section{DATA AVAILABILITY STATEMENT}

All datasets generated for this study are included in the article/supplementary material.

\section{ETHICS STATEMENT}

Written informed consent was obtained from the individual(s) for the publication of any potentially identifiable images or data included in this article.

\section{AUTHOR CONTRIBUTIONS}

YS and LC participated in writing the manuscript. MZ and $\mathrm{YL}$ participated in collecting the information of the paper and analysis or interpretation of data. YZ participated in revising the manuscript. All authors contributed to the article and approved the submitted version.

\section{FUNDING}

This work was supported by Natural Science Foundation of China (No. 81974194) (to YZ), by Jilin Province Health and Family Planning Commission (No. 2018J045) (to YZ).
4. Morise S, Nakamura M, Morita JI, Miyake K, Kunieda T, Kaneko S, et al. Thymoma-associated Progressive Encephalomyelitis with Rigidity and Myoclonus (PERM) with myasthenia gravis. Intern Med. (2017) 56:1733-7. doi: 10.2169/internalmedicine.56.7979

5. Ozaki K, Ohkubo T, Yamada T, Yoshioka K, Ichijo M, Majima T, et al. Progressive encephalomyelitis with rigidity and myoclonus resolving after thymectomy with subsequent anasarca: an autopsy case. Intern Med. (2018) 57:3451-8. doi: 10.2169/internalmedicine.1 238-18

6. Borellini L, Lanfranconi S, Bonato S, Trezzi I, Franco G, Torretta L, et al. Progressive encephalomyelitis with rigidity and myoclonus associated with Anti-GlyR antibodies and hodgkin's lymphoma: a case report. Front Neurol. (2017) 8:401. doi: 10.3389/fneur.2017.00401 
7. Schmidt C, Freilinger T, Lieb $M$, Rémi J, Klein $M$, Straube $A$, et al. Progressive encephalomyelitis with rigidity and myoclonus preceding otherwise asymptomatic Hodgkin's lymphoma. J Neurol Sci. (2010) 291:11820. doi: 10.1016/j.jns.2009.12.025

8. Tchapyjnikov D, Borst AJ. Immune-related neurological symptoms in an adolescent patient receiving the checkpoint inhibitor nivolumab. $J$ Immunother. (2017) 40:286-8. doi: 10.1097/CJI.0000000000000177

9. Spitz M, Ferraz HB, Barsottini OG, Gabbai AA. Progressive encephalomyelitis with rigidity: a paraneoplastic presentation of oat cell carcinoma of the lung. case report. Arq Neuropsiquiatria. (2004) 62:547-9. doi: 10.1590/S0004-282X2004000300033

10. Kyskan R, Chapman K, Mattman A, Sin D. Antiglycine receptor antibody and encephalomyelitis with rigidity and myoclonus (PERM) related to small cell lung cancer. BMJ Case Rep. (2013) 2013:bcr2013010027. doi: 10.1136/bcr-2013-010027

11. De Blauwe SN, Santens P, Vanopdenbosch LJ. Anti-glycine receptor antibody mediated progressive encephalomyelitis with rigidity and myoclonus associated with breast cancer. Case Rep Neurol Med. (2013) 2013:589154. doi: 10.1155/2013/589154

12. Dalakas MC. Stiff person syndrome: advances in pathogenesis and therapeutic interventions. Curr Treat Options Neurol. (2009) 11:102-10. doi: 10.1007/s11940-009-0013-9

13. Whiteley AM, Swash M, Urich H. Progressive encephalomyelitis with rigidity. Brain. (1976) 99:27-42. doi: 10.1093/brain/99.1.27

14. Lynch JW. Native glycine receptor subtypes and their physiological roles. Neuropharmacology. (2009) 56:303-9. doi: 10.1016/j.neuropharm.2008. 07.034

15. Gresa-Arribas N, Ariño H, Martínez-Hernández E, Petit-Pedrol M, Sabater L, Saiz A, et al. Antibodies to inhibitory synaptic proteins in neurological syndromes associated with glutamic acid decarboxylase autoimmunity. PLoS ONE. (2015) 10:e121364. doi: 10.1371/journal.pone.01 21364

16. Balint B, Bhatia KP. Stiff person syndrome and other immune-mediated movement disorders - new insights. Curr Opin Neurol. (2016) 29:496-506. doi: 10.1097/WCO.0000000000000351

17. Kraemer M, Berlit P. Progressive encephalomyelitis with rigidity and myoclonus in an 81-year-old patient. Clin Neurol Neurosurg. (2008) 110:27981. doi: 10.1016/j.clineuro.2007.10.004

18. Shugaiv E, Leite MI, Sehitoglu E, Woodhall M, Çavuş F, Waters P, et al. Progressive encephalomyelitis with rigidity and myoclonus: a syndrome with diverse clinical features and antibody responses. Eur Neurol. (2013) 69:25762. doi: 10.1159/000342237

19. Howell DA, Lees AJ, Toghill PJ. Spinal internuncial neurones in progressive encephalomyelitis with rigidity. J Neurol Neurosurg Psychiatry. (1979) 42:77385. doi: 10.1136/jnnp.42.9.773

20. McCombe PA, Chalk JB, Searle JW, Tannenberg AE, Smith JJ, Pender MP. Progressive encephalomyelitis with rigidity: a case report with magnetic resonance imaging findings. J Neurol Neurosurg Psychiatry. (1989) 52:142931. doi: 10.1136/jnnp.52.12.1429

21. Joanna Ball Andrew J. David J Burn. MATTERS ARISING: a case of progressive encephalomyelitis with rigidity and positive antiglutamic acid dehydrogenase antibodies. J Neurol Neurosurg Psychiatry. (1991) 54:1032. doi: 10.1136/jnnp.54.11.1032-e

22. Kullmann DM, Howard RS, Miller DH, Hirsch NP, Brown P, Marsden CD. Brainstem encephalopathy with stimulus-sensitive myoclonus leading to respiratory arrest, but with recovery: a description of two cases and review of the literature. Mov Disord. (1996) 11:715-8. doi: 10.1002/mds.8701 10618

23. Back T, Stoltenburg-Didinger G, Ploner CJ, Meisel H, Zschenderlein R. A new variant of progressive encephalomyelitis with rigidity associated with cerebellar ataxia and dementia: correlation of MRI and histopathological changes. a case report. Neurol Res. (1997) 19:187-91. doi: 10.1080/01616412.1997.11740794

24. Saidha S, Elamin M, Mullins G, Chaila E, Tormey VJ, Hennessy MJ. Treatment of progressive encephalomyelitis with rigidity and myoclonic jerks with rituximab: a case report. Eur J Neurol. (2008) 15:e33. doi: $10.1111 /$ j.1468-1331.2008.02089.x
25. Hutchinson M, Waters P, McHugh J, Gorman G, O'Riordan S, Connolly $S$, et al. Progressive encephalomyelitis, rigidity, and myoclonus: a novel glycine receptor antibody. Neurology. (2008) 71:1291-2. doi: 10.1212/01.wnl.0000327606.50322.f0

26. Mas N, Saiz A, Leite MI, Waters P, Baron M, Castaño D, et al. Antiglycinereceptor encephalomyelitis with rigidity. I Neurol Neurosurg Psychiatry. (2011) 82:1399-401. doi: 10.1136/jnnp.2010.229104

27. Turner MR, Irani SR, Leite MI, Nithi K, Vincent A, Ansorge O. Progressive encephalomyelitis with rigidity and myoclonus: glycine and NMDA receptor antibodies. Neurology. (2011) 77:439-43. doi: 10.1212/WNL.0b013e318227b176

28. Iizuka T, Leite MI, Lang B, Waters $\mathrm{P}$, Urano $\mathrm{Y}$, Miyakawa $\mathrm{S}$, et al. Glycine receptor antibodies are detected in progressive encephalomyelitis with rigidity and myoclonus (PERM) but not in saccadic oscillations. J Neurol. (2012) 32:544-9.

29. Peeters E, Vanacker P, Woodhall M, Vincent A, Schrooten M, Vandenberghe W. Supranuclear gaze palsy in glycine receptor antibody-positive progressive encephalomyelitis with rigidity and myoclonus. Mov Disord. (2012) 27:18302. doi: $10.1002 / \mathrm{mds} .25239$

30. Damásio J, Leite MI, Coutinho E, Waters P, Woodhall M, Santos MA, et al. Progressive encephalomyelitis with rigidity and myoclonus: the first pediatric case with glycine receptor antibodies. JAMA Neurol. (2013) 70:498-501. doi: 10.1001/jamaneurol.2013.1872

31. Stern WM, Howard R, Chalmers RM, Woodhall MR, Waters P, Vincent A, et al. Glycine receptor antibody mediated Progressive Encephalomyelitis with Rigidity and Myoclonus (PERM): a rare but treatable neurological syndrome. Pract Neurol. (2014) 14:123-7. doi: 10.1136/practneurol-2013-000511

32. Wuerfel E, Bien CG, Vincent A, Woodhall M, Brockmann K. Glycine receptor antibodies in a boy with focal epilepsy and episodic behavioral disorder. $J$ Neurol Sci. (2014) 343:180-2. doi: 10.1016/j.jns.2014.05.014

33. Balint B, Jarius S, Nagel S, Haberkorn U, Probst C, Blöcker IM, et al. Progressive encephalomyelitis with rigidity and myoclonus: a new variant with DPPX antibodies. Neurology. (2014) 82:1521-8. doi: 10.1212/WNL.0000000000000372

34. Bourke D, Roxburgh R, Vincent A, Cleland J, Jeffery O, Dugan N, et al. Hypoventilation in glycine-receptor antibody related progressive encephalomyelitis, rigidity and myoclonus. J Clin Neurosci. (2014) 21:876-8. doi: 10.1016/j.jocn.2013.07.014

35. Seguier J, Serratrice J, Lachaud A, Belenotti P, Benyamine A, Verschueren A, et al. [Abdominal pain in progressive encephalomyelitis with rigidity]. Rev Med Interne. (2015) 36:283-6. doi: 10.1016/j.revmed.2013.12.019

36. Ueno S, Miyamoto N, Shimura H, Ueno Y, Watanabe M, Hayashi A, et al. Successful immune moderation treatment for progressive encephalomyelitis with rigidity and myoclonus. Intern Med. (2015) 54:219-21. doi: 10.2169/internalmedicine. 54.3760

37. Kenda J, Švigelj V, Rodi Z, Koritnik B, Graus F, Kojović M. Glycine receptor antibodies and progressive encephalomyelitis with rigidity and myoclonus with predominant motor neuron degeneration-expanding the clinical spectrum. J Neurol Sci. (2015) 353:177-8. doi: 10.1016/j.jns.2015.03.049

38. Degeneffe A, Dagonnier M, D'hondt A, Elosegi JA. A case report of rigidity and recurrent lower limb myoclonus: progressive encephalomyelitis rigidity and myoclonus syndrome, a chameleon. BMC Neurol. (2018) 18:173. doi: 10.1186/s12883-018-1176-3

39. Wirth T, Kaeuffer C, Chanson JB, Echaniz-Laguna A, Renaud M, Anheim M, et al. Progressive encephalomyelitis with rigidity and myoclonus, a diagnostic challenge. Rev Neurol. (2018) 174:343-6. doi: 10.1016/j.neurol.2017. 09.012

40. Witek N, Hebert C, Gera A, Comella C. Progressive Encephalomyelitis With Rigidity and Myoclonus Syndrome Presenting as Catatonia. Psychosomatics. (2019) 60:83-7. doi: 10.1016/j.psym.2018.05.005

41. Jazebi N, Rodrigo S, Gogia B, Shawagfeh A. Anti-glutamic acid decarboxylase (GAD) positive cerebellar Ataxia with transitioning to progressive encephalomyelitis with rigidity and myoclonus (PERM), responsive to immunotherapy: a case report and review of literature. J Neuroimmunol. (2019) 332:135-7. doi: 10.1016/j.jneuroim.2019.04.003

42. Duddy ME, Baker MR. Stiff person syndrome. Front Neurol Neurosci. (2009) 26:147-65. doi: 10.1159/000212375 
43. Baizabal-Carvallo JF, Jankovic J. Stiff-person syndrome: insights into a complex autoimmune disorder. J Neurol Neurosurg Psychiatry. (2015) 86:8408. doi: 10.1136/jnnp-2014-309201

Conflict of Interest: The authors declare that the research was conducted in the absence of any commercial or financial relationships that could be construed as a potential conflict of interest.
Copyright $\odot 2020 \mathrm{Su}, \mathrm{Cui}$, Zhu, Liang and Zhang. This is an open-access article distributed under the terms of the Creative Commons Attribution License (CC BY). The use, distribution or reproduction in other forums is permitted, provided the original author(s) and the copyright owner(s) are credited and that the original publication in this journal is cited, in accordance with accepted academic practice. No use, distribution or reproduction is permitted which does not comply with these terms. 